\title{
Diversity and morphological disparity of desmid assemblages in Central European peatlands
}

\author{
Jiří Neustupa $\cdot$ Kateřina Černá · Jan Št’astný
}

Received: 5 March 2009/Revised: 21 April 2009/Accepted: 24 April 2009/Published online: 10 May 2009

(C) Springer Science+Business Media B.V. 2009

\begin{abstract}
Morphological disparity has increasingly been used as an alternative measure of biological diversity based on the shape features of organisms. In this study, we investigated the species diversity and morphological disparity of benthic Desmidiales in Central European peatland pools. The shape features of cells were determined using the 3-D elliptical Fourier analysis of their frontal and lateral views. The resulting morphospace was used to calculate the contributions of localities and species to the morphological variation. In addition, the disparity of samples and their average cell complexity (indicating intricacy of cell shapes) was evaluated. These data were related to species diversity data and to the abiotic factors. Species diversity was positively correlated with $\mathrm{pH}$ and conductivity. The low-pH localities generally supported a more variable species composition than did slightly acidic to neutral localities.
\end{abstract}

Handling editor: J. Padisak

Electronic supplementary material The online version of this article (doi:10.1007/s10750-009-9799-4) contains supplementary material, which is available to authorized users.

J. Neustupa $(\varangle) \cdot$ K. Černá $\cdot$ J. Št'astný

Faculty of Science, Department of Botany, Charles

University of Prague, Benátská 2, 12801 Praha,

Czech Republic

e-mail: neustupa@natur.cuni.cz
Conversely, the total nitrogen concentrations of these areas negatively correlated with species diversity. Interestingly, partial morphological disparity (measuring the contribution of a sample to the overall morphological variation) did not correlate with species diversity. On the contrary, several mountain peat bog localities had high disparity values, irrespective of their rather low species diversity. In addition, several samples from minerotrophic fens with high diversity had average or low values of partial morphological disparity. These results indicate the relative importance of mountain peat bogs for the total morphological diversity of Desmidiales within the region that could not be ascertained solely from species diversity data. The inner morphological disparity of samples was highly correlated with their species diversity. Species of the genus Micrasterias, Hyalotheca dissiliens and Desmidium species had the highest partial morphological disparity, thus indicating their marginal position within the morphospace. Micrasterias and Euastrum species had the highest complexity values. The average cell complexity of individual samples did not correlate with their diversity or disparity; however, it was positively correlated with the levels of total nitrogen and phosphorus, and illustrates a pattern different from that arrived at by species diversity data.

Keywords Desmidiales - Elliptic Fourier analysis · Geometric morphometrics - Peat bogs · Morphological disparity 


\section{Introduction}

Biological diversity may be quantified by different methods based on various aspects of organisms (Magurran, 2004). Species (or taxonomic) richness has traditionally been the dominating approach in studies of algal biodiversity, including that of the Desmidiales. However, new biodiversity concepts, including molecular phylogenetic diversity (Purvis \& Hector, 2000) and morphological disparity (Roy \& Foote, 1997), provide intriguing ways of investigating different aspects of temporal and spatial variation in nature. In general, phylogenetic diversity reflects the sum of phylogenetic distances between individual members of an assemblage (Purvis \& Hector, 2000). Morphological diversity (or disparity) is based on a morphometric distance that quantifies the shape differences of assemblage members (Roy \& Foote, 1997). The multivariate space of a complete investigated set of organisms (spanned e.g. by axes of PCA of morphometric data) is called morphospace (Foote, 1993; Roy et al., 2001). Distances in morphospace (e.g. Euclidean distances between the overall mean and individual objects) may be used for calculation of morphological disparity - either of a set as a whole, or of its individual members or subgroups. Several studies have demonstrated that morphological disparity may not be correlated with taxonomic or phylogenetic diversity (Roy et al., 2001; Neige, 2003a). However, comparison of taxonomic (species) richness with morphological disparity provides a unique way of evaluating diversity across different localities or habitat types. One particular feature of morphological disparity is that individual species contribute differently to the morphological disparity of a community or sample. The contribution of individual specimens is weighted by their position in morphospace: the more morphologically eccentric, the greater its contribution to sample disparity. The concept of morphological disparity has recently been applied in an analysis of spatial or temporal patterns in communities of different organisms (e.g. Roy et al., 2001; Neige, 2003a, b, 2006-cuttlefishes; McClain et al., 2004-gastropods; Clabaut et al., 2007; Hoagstrom \& Berry, 2008-freshwater fishes). Neige (2003a, 2006) reported differences in regional values of disparity versus species richness in cuttlefish. The highly diverse West Pacific region, considered a centre of origin for this group, was accompanied by relatively low disparity. This was interpreted as an example of low morphological diversity in a region considered as the primary centre of diversity containing a high proportion of species with morphologies close to the centroid of the group morphospace. Similarly, Roy et al. (2001) demonstrated low regional species richness of marine strombid gastropods that, however, had high or above-average morphological disparity. They stressed the conservational importance of regions that, notwithstanding their low species diversity, contain a significant proportion of the morphospace variation of the group. McClain et al. (2004) reported comparable levels of gastropod disparity in lower bathyal and abyssal marine habitats, even though species richness was lower in the latter communities. On the other hand, Hoagstrom \& Berry (2008) detected similar trends in species diversity and disparity in communities of river fishes, and interpreted this as higher niche heterogeneity of habitats with a high species number.

The present study represents the first disparity analysis of natural protist assemblages. The Desmidiales were chosen as a species-rich monophyletic group of green algae (Gontcharov, 2008; Hall et al., 2008), typically inhabiting benthic freshwater environments (Coesel \& Meesters, 2007). Natural assemblages of desmids are known to subtly reflect the environmental conditions of localities (e.g. Lenzenweger, 2003). Coesel (2001, 2003) developed an intriguing system of conservational evaluation of peatland localities on the basis of their desmid species composition. Mature cells of desmids have fixed shapes as they are surrounded by cell walls. At the same time, the Desmidiales are one of the most conspicuous protists. With their elaborate cell shapes, they have long attracted the attention of morphologists (Ralfs, 1848). Even the traditional names of desmids in several languages reflect the shape complexity or ornamentation of their cells ('krásivky' in Czech is little beauties, 'Zieralgen' in German is beautiful algae). The quantitative shape information of desmid cells has recently been used in several geometric morphometric studies that concentrated on taxonomy (Neustupa \& Št'astný, 2006; Neustupa \& Škaloud, 2007), and the temperature-related plasticity of the genus Micrasterias (Neustupa et al., 2008). At the same time, the morphological variation of desmids was also studied by means of traditional 
morphometric methods utilizing measurements of distances and angles of cells (e.g. Bicudo \& Gil-Gil, 2003). However, the disparity of species-rich natural desmid assemblages and the relation of disparity to their taxonomic diversity have not, thus far, been investigated. The Desmidiales often dominate in phytobenthos of peatland localities (Borics et al., 2003; Coesel \& Meesters, 2007). Růžička (1977) and Coesel (2001) suggested that species richness optima of desmid assemblages can usually be found in slightly acidic wetlands with a $\mathrm{pH}$ of approximately 5.5-6.5. According to Vitt (2006), these values correspond to the upper $\mathrm{pH}$ ranges of most temperate and boreal peatland habitats. The relation of species richness and the $\mathrm{pH}$ of the water environment have often been investigated. Mataloni (1999) revealed the $\mathrm{pH}$-related increase in species diversity of desmids in peat bogs of Tierra del Fuego in temperate South America. Coesel et al. (1978) demonstrated a decrease in species richness of the Desmidiales related to anthropogenic acidification of peatland localities in the Netherlands. Meanwhile, Tomaszewicz (1994), Nováková (2002) and Štěpánková et al. (2008) reported a positive relation of desmid diversity and $\mathrm{pH}$ in temperate European peat bogs. In addition, Štépánková et al. (2008) also illustrated the significant positive relation of conductivity and diversity of desmids in mountain peat bogs. Coesel et al. (1978), Gilbert et al. (1998) and Wayda (2004) observed a decrease of peatland desmid species diversity as a result of eutrophication of previously mesotrophic, slightly acidic wetland habitats. In a unique study involving analyses of morphology-toecology relations in desmid assemblages, Coesel (1982) investigated an extensive set of samples from Dutch fens and marshes. He suggested that, apart from decreased species richness, low $\mathrm{pH}$ conditions $(<4.0)$ in mire habitats generally correlated with a higher frequency of species with simple, cylindrical shapes; although, most of them were, however, the unicellular Mesotaeniaceae that do not actually belong to Desmidiales. Desmid species with more complex, ornamented cells typically occurred in localities with a pH higher than 5.0. However, Coesel's (1982) observations did not involve explicit quantitative analyses of shape variation in relation to abiotic factors.

Recently, the geometric morphometric methods (including outline-based analyses) have increasingly been applied in phycology (e.g. Pappas et al., 2001; Beszteri et al., 2005, Potapova \& Hamilton, 2007), including studies of desmids (Neustupa \& Škaloud, 2007; Neustupa et al., 2008). This methodological advancement now allows one to investigate the morphospace structure of natural desmid assemblages in phytobenthos. In this study, we selected 30 Central European peatlands, including ombrotrophic peat bogs and minerotrophic fens, spanning a $\mathrm{pH}$ range from 3.9 to 7.0, for investigation of diversity versus disparity patterns of their benthic desmid assemblages. We asked the following questions:

(a) What is the relation between species diversity of benthic assemblages of the Desmidiales and abiotic parameters of localities?

(b) What is the morphospace structure of Central European peatland desmid assemblages and what are the individual species contributions to the overall morphological disparity of an entire set of investigated localities?

(c) Is there any relation between local species diversity and morphological disparity measures?

(d) Is there any relation between local disparity values of desmid assemblages and abiotic factors of localities?

\section{Materials and methods}

Localities and processing of samples

The 30 investigated localities (Fig. 1; Table 1Electronic supplementary material to this article) were sampled in July and August 2008. By selection of these localities, we aimed to span the principal environmental gradients that structure peatland freshwater habitats of the region (minerotrophy versus ombrotrophy, strongly acidic bogs versus mesotrophic peatlands). The majority of the sampled localities were located in the Czech Republic, where most of the important existing peatland habitats were included. In addition, we sampled several interesting localities in adjacent countries. The minerotrophic mountain bogs of the Vihorlat Mts., Slovakia, and Rhön Mts. Germany, were included as the examples of otherwise rare habitat type. In addition, four samples from Pohorje Mts., Slovenia, which represent the acidic mountain bog habitats were also 
included. At each locality, we sampled $0.25 \mathrm{~m}^{2}$ quadrates of a phytobenthic community. The $\mathrm{pH}$ and conductivity values were measured in the field using the combined pH/conductometer WTW 340i. The inorganic forms of nitrogen and phosphorus were measured by the Hach colorimeter DR/890. The $\mathrm{NH}_{4}{ }^{+}$concentrations were evaluated using the salicylate method (Hach ammonia kit, method no. 10023). The nitrates $\left(\mathrm{NO}_{3}{ }^{-}\right)$were evaluated using the cadmium reduction method (Hach nitrate kit, method no. 8171). The total nitrogen concentrations were measured using the persulfate digestion method, which consists of a conversion of all forms of nitrogen to nitrate in an alkaline persulfate digestion and subsequent reaction of nitrate with chromotropic acid under strongly acidic conditions (Hach total nitrogen kit, method no. 10071). The reactive phosphorus (orthophosphate) was estimated using the ascorbic acid method (Hach reactive phosphorus kit, method no. 8048), where the orthophosphates react with molybdate in an acid medium to produce a phosphomolybdate complex; ascorbic acid then reduces the complex, giving an intense molybdenum blue color. Finally, the total phosphorus concentrations were evaluated using the acid persulfate digestion method (Hach total phosphorus kit, method no. 8190). In this method, all the organic and condensed inorganic forms of phosphates in the sample are converted to orthophosphates by heating with acid and persulfate. The subsequent reactions are identical to those described above for estimation of orthophosphates. The samples for species identification were immediately fixed and desmids were determined by examination under an Olympus BX51 light microscope using Nomarski differential contrast. We randomly photographed 100 desmid cells in each sample that were also used for disparity analyses. The occasional long filaments of several trichal desmid species (e.g. Hyalotheca dissiliens or Desmidium aptogonum) were counted up to 10 cells.

\section{Morphometric methods}

In total, 3,000 objects were used for the disparity analysis. In each species, a complete cell with two mature semicells was chosen, and its shape was registered by the following procedure. In total, 56 two-dimensional points (landmarks) were placed regularly along the outline of mature cells using

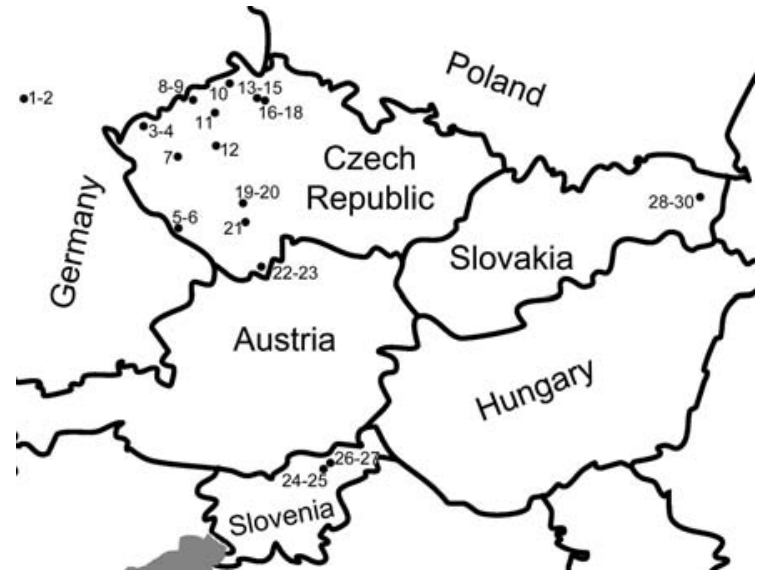

Fig. 1 The map of the investigated localities

TpsDig, ver 2.12. (Rohlf, 2008) to capture their frontal view. The $z$ coordinates of these landmarks were set to zero. The 3-D shape dimension (lateral view outlines) of cells with circular or elliptical apical view outlines was approximated using the published data on width-to-thickness ratios of individual species (extracted from Coesel \& Meesters, 2007; Prescott et al., 1977; Růžička, 1977, 1981). This was then used to calculate 54 points approximating the lateral view outline of cells from the $x$ and $y$ positions of landmarks registered along the frontal view outline (see above). The $x$ and $y$ coordinates of lateral view landmarks were obtained as averages of the respective 2-D frontal view landmarks. The $z$ coordinates of lateral view landmarks were calculated from data on width-to-thickness ratios of individual species. The R, ver. 2.3.1. software for statistical computing ( $\mathrm{R}$ Core Development Team, 2006) was used to compute lateral view landmarks. In triradiate (or rare tetraradiate species), the lateral view was approximated by calculating the position of landmarks in third (fourth) lobe using the position of points along the outline in a frontal view.

The total 110 points spanning the frontal and lateral views of cell outlines were subjected to 3-D elliptic Fourier analysis (Lestrel, 2000; Rohlf, 2003) for calculation of coefficients describing the shape properties of individual species. One major advantage of the elliptic Fourier analysis (EFA) is that it does not rely on the homology or geometric correspondence of individual landmarks (Lestrel, 1997), as is e.g. the case in the general Procrustes analysis (Zelditch et al., 2004). Instead, the EFA calculates the coefficients of 
harmonic functions describing shape properties of the entire outline. In our dataset, consisting of widely dissimilar shapes from elongate Closterium and Pleurotaenium cells to complex, deeply lobed species of Micrasterias, the homology (or geometric correspondence) criterion would probably be questionable. In addition, when using the general Procrustes analysis, the extremely high amount of variation, presumed in this species-rich dataset of benthic Desmidiales, could result in distortion of the tangent space projected from the original shape space of Procrustes coordinates (Dryden \& Mardia, 1998). However, the EFA demands a single, homologous starting point for all the analyzed objects (cells). In Desmidiales, the choice of such a point was obvious: the apical tip of a semicell that was unambiguously evident in all the investigated species. The cells of desmids are bilaterally symmetrical, but in this study, we concentrated on disparity analyses, and symmetry/asymmetry issues were not investigated.

The original configurations of points describing outlines were replaced so that the starting point at the centre of the polar lobe of a semicell had zero coordinates. Second, the configurations were optimally rotated and scaled to a unit centroid size, the square root of the sum of squared distances from the landmarks to their centroid (Dryden \& Mardia, 1998) in PAST, ver. 1.88 (Hammer et al., 2001). Third, the 3D elliptic Fourier analysis was conducted using EFA3D, ver. 1.0 (Rohlf, 2003). In total, the 25 harmonic functions sufficiently spanning the shape of the cells (Fig. 2) were used for the subsequent analysis.

\section{Disparity analyses}

The principal component analysis (PCA) based on the variance-covariance matrix of the coefficients of harmonic functions from the EFA was used to simplify the multivariate set. For subsequent analyses, we used the first 10 PC axes spanning $98.1 \%$ of the total variation that was found significant by the Joliffe cut-off value (Jolliffe, 1986). The multivariate set of 3,000 objects characterized by their scores on these 10 PC axes constituted the morphospace for the disparity analysis.

The disparity was analyzed in several different ways. Initially, the partial morphological disparity of localities (Foote, 1993; Zelditch et al., 2004), indicating the contribution of a sample to the overall morphospace of the investigated set, was calculated. The morphological disparity of the entire set was calculated following the Footes (1993) index:

$\mathrm{MD}=\frac{\sum_{i=1}^{N}\left(D_{i}^{2}\right)}{(N-1)}$

where $D_{i}$ is Procrustes distance of an individual object to reference form and $N$ is number of objects. The contribution of each object to the overall morphological disparity of the set can be expressed as partial morphological disparity:

$\mathrm{PD}=\frac{D_{i}^{2}}{N-1}$

We see that the sum of PD values of all objects equals the value of morphological disparity index of the whole set. First, the partial morphological disparity of a particular locality was evaluated as sum of PD values of its 100 cells. This measure gives the contribution of a locality assemblage to the overall morphological disparity of desmids in investigated peatlands. At the same time, the species partial morphological disparity was evaluated as sum of PD values of cells identified as a particular species in an investigated set of 3,000 cells. Second, we also evaluated the partial morphological disparity based just on the presence/absence of species at the localities. The partial morphological disparity (a)

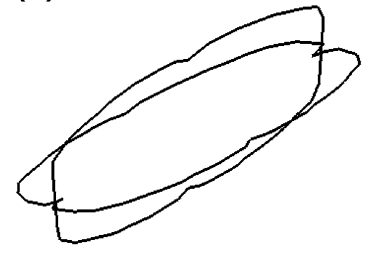

(b)

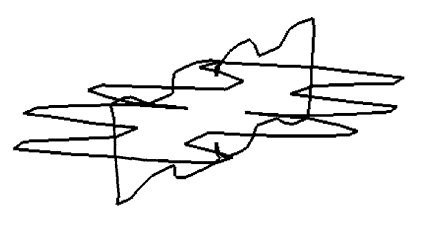

(c)

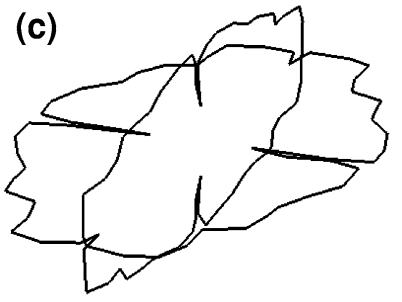

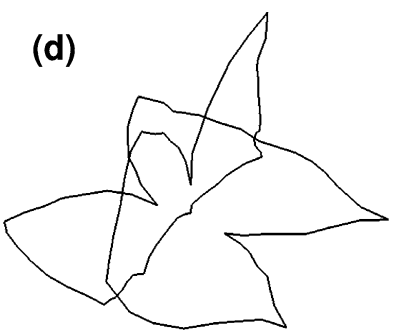

Fig. 2 The outlines of frontal and lateral views reconstructed from the 3-D elliptic Fourier analysis. a Tetmemorus laevis; b Micrasterias pinnatifida; c Euastrum humerosum; d Staurastrum furcatum var. aciculiferum 
of localities based on this presence/absence matrix was calculated by the same equations as in the previous case.

Apart from the partial morphological disparity of individual localities that accounted for their contribution to the overall disparity of the complete set, we also calculated the disparity of a sample, or the inner morphological disparity (ID). This measure evaluated the morphological dissimilarity of individual localities. It was calculated as the sum of Euclidean distances between all the 100 objects (cells) of a particular locality in the overall morphospace of 3,000 objects. As another morphological measure, we also evaluated the $C$ value that indicated complexity of a cell shape. For each species, this measure was calculated as the sum of Euclidean distances between adjacent landmarks along the outline in the size-standardized configurations of 110 landmarks along frontal and lateral views of cells:

$C=\sum_{i=1}^{N} \sqrt{\left(p_{x i}-p_{x i+1}\right)^{2}+\left(p_{y i}-p_{y i+1}\right)^{2}+\left(p_{z i}-p_{z i+1}\right)^{2}}$

where $p_{i}$ is the $i$ th landmark of the configuration with $p_{x i}, p_{y i}$ and $p_{z i}$ indicating its $x, y$ and $z$ coordinates, respectively. An ideal sphere would have minimal $C$ value, and its increase reflects deviation of cell shape from circularity.

\section{Species data analyses}

The patterns of species composition among localities were illustrated using the non-metric dimensional scaling (NMDS) with Euclidean distance measure in PAST, ver. 1.88 (Hammer et al., 2001). The Kruskal stress value was used as the measure of goodness of fit in representation of actual multivariate distances between localities in resulting NMDS ordination diagram (Kruskal, 1964). The effects of abiotic factors on species composition of localities were evaluated by Mantel tests of matrix correlations (Mantel, 1967; Fortin \& Gurevitch, 1993). The similarity in species composition was evaluated using matrix of Euclidean distances between localities. Matrix $X$ of differences in values of abiotic factors was evaluated as follows:

$X=\left[\left|a_{i}-b_{i}\right|\right]_{m \times m}$

where $a_{i}$ and $b_{i}$ are individual values of compared abiotic factors of $m$ localities (Fortin \& Gurevitch,
1993). Significance of matrix correlations was evaluated by 10,000 permutations in PAST, ver. 1.88. Species diversity was evaluated by Shannon-Wiener index (Magurran, 2004) and by species richness. Relation of species diversity, morphological disparity measures and abiotic factors were evaluated by linear correlation analyses with the permutation $P$-value based on 10,000 randomizations.

\section{Results}

Of the 3,000 desmid cells from 30 investigated samples, we identified 155 taxa. The descriptions and abiotic data of localities and the complete list of species in localities and their abbreviations are accessible in the Electronic supplementary material (Table 1-Electronic supplementary material). The maximum species richness was found in slightly acidic samples from the 'Břehyně' and 'Swamp' wetlands (samples no. 16-32 species; no. 13-21 species) and from 'Novohradské hory' Mts. (sample no. 22-26 species). On the other hand, several bog localities clearly had low species richness and alfadiversity (see Table 2 as Electronic supplementary material) with just three species in 'Novodomské rašeliniště' peat bog (sample no. 8) and in 'Hybkaňa' peat bog, Vihorlat Mts., Slovakia (sample no. 30).

The NMDS ordination of samples by their species composition illustrated that the low-pH localities had quite variable species composition that positioned them typically on the margins of the ordination space (Fig. 3). Interestingly, most higher-pH localities appeared to have a more similar species composition. In order to test this observation, we separately evaluated the Euclidean distances between pairs of localities, based on their species composition, in three groups defined by their $\mathrm{pH}-$ level $(\mathrm{pH}<5.0, \mathrm{pH} 5.0-6.0$ and $\mathrm{pH}>6.0)$. The permutation $t$-tests $(10,000$ permutations) on differences in means of these three sets revealed that the low-pH localities had significantly higher variation of species composition than localities with a pH between 5.0 and $6.0(P$-value $=0.0001$, low$\mathrm{pH}$ group mean $=89.7$, slightly acidic group mean $=61.3$ ). In addition, the low-pH localities were more variable in their species composition than those with $\mathrm{pH}$ higher than $6.0(P$-value $=0.0001$, high-pH group mean $=61.2)$. On the other hand, the localities with slightly acidic $\mathrm{pH}(5.0-6.0)$, and those with a $\mathrm{pH}$ 

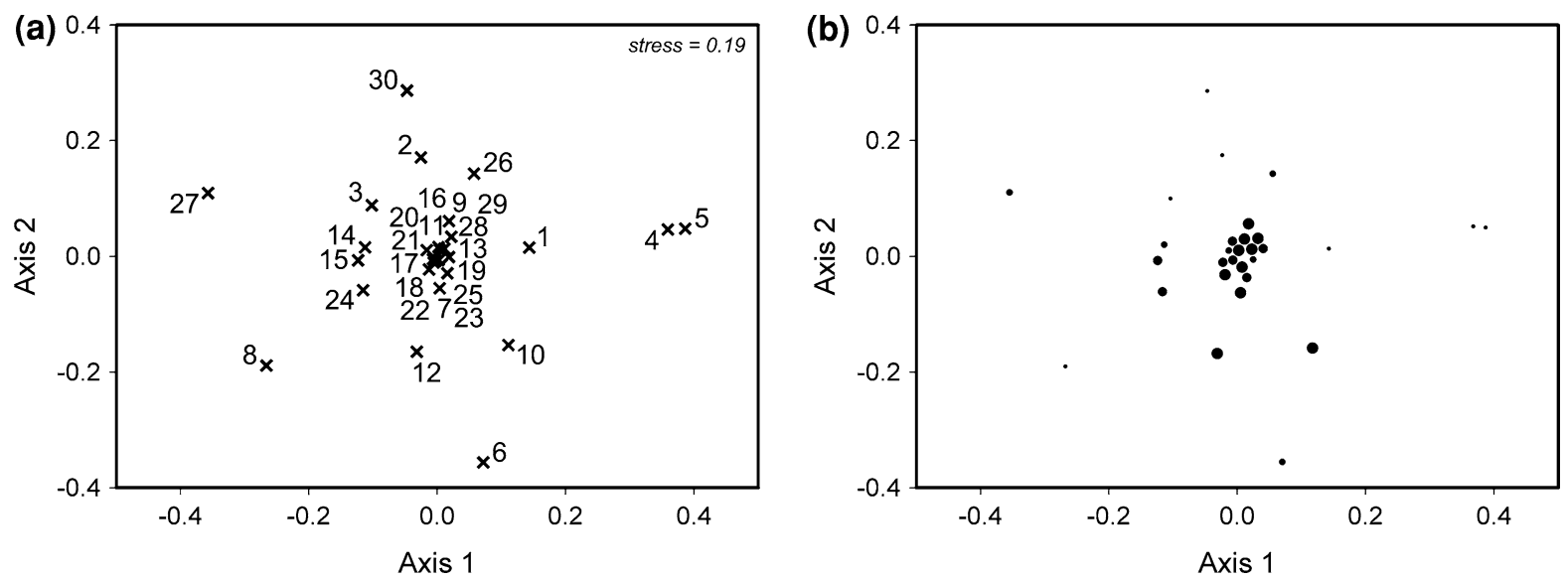

Fig. 3 The NMDS ordination plot of localities based on their species composition (a) and the same plot with the symbol sizes reflecting the $\mathrm{pH}$ values of the localities $(\mathbf{b})$

higher than 6.0, had similar levels of variation in their species composition $(P$-value $>0.05)$.

The Mantel tests revealed that $\mathrm{pH}(r=0.33$, $P=0.0001)$ and total nitrogen $(r=0.27$, $P=0.0071)$ were the only significant abiotic factors correlating with species composition of the localities. The $\mathrm{pH}$ of the localities was positively correlated with the conductivity $(r=0.61, P=0.0003)$, the total nitrogen content was positively correlated with total phosphorus $(r=0.49, P=0.005)$ and the area of the localities was positively correlated with their depth $(r=0.44, P=0.013)$. Other abiotic factors were not significantly correlated. Species diversity (evaluated by the Shannon-Wiener index) positively correlated with $\mathrm{pH}$ of the localities $(r=0.73$, $P<0.0001)$, and with conductivity $(r=0.40, P=$ 0.026) (Fig. 4a, b), whereas there was a weakly significant negative correlation of species diversity with total nitrogen concentrations $(r=-0.38$, $P=0.037$ ) (Fig. 4c). Relations of species diversity and other abiotic factors were insignificant.

The PCA of 3-D elliptic Fourier coefficients in the entire set illustrated that the elongated species (e.g. members of the genera Closterium, Penium or Pleurotaenium) were separated from other species along the first PC axis (Fig. 5). Species of Tetmemorus and Actinotaenium were generally in an intermediate position between elongated and compressed forms. The triradiate cells of Staurastrum and Desmidium species were separated from species with the elliptical apical view outline along the second $\mathrm{PC}$ axis. The third and fourth PC axes mainly separated Micrasterias species from the others, and on the opposite extremity of the third PC axis, Hyalotheca dissiliens, Desmidium grevillei and Staurastrum controversum were clustered. A group of triradiate species was separated from the others by positive values of the fourth PC axis. Species of individual traditional genera often had similar values, either of partial morphological disparity (PD) or complexity (C) (Fig. 6). While we know that most of these genera are, in fact, polyphyletic or paraphyletic (Gontcharov, 2008; Hall et al. 2008), the similarity of their disparity or complexity is not surprising, given the fact that they have been defined almost entirely on the basis of morphological data. Members of the genus Micrasterias generally had the highest partial morphological disparities (PD), indicating their large contribution to the total morphological disparity of the entire set (Fig. 6a; Electronic supplementary Material). Staurastrum pseudotetracerum, S. minimum, Desmidium grevillei, D. aptogonum and Hyalotheca dissiliens were the other species with high partial morphological disparities, while most Cosmarium and Closterium species had average PD values. Species of Tetmemorus and Euastrum typically had low partial morphological disparities, indicating their overall central position within the morphospace.

The measure of morphological disparity of localities (PD) determined their contribution to the total morphological disparity (MD) of the entire set, and revealed a pattern uncorrelated with species diversity (Fig. 4d). Neither the partial morphological disparity of localities based on the quantitative counts, nor the $\mathrm{PD}$ values of localities based on the presence/absence 

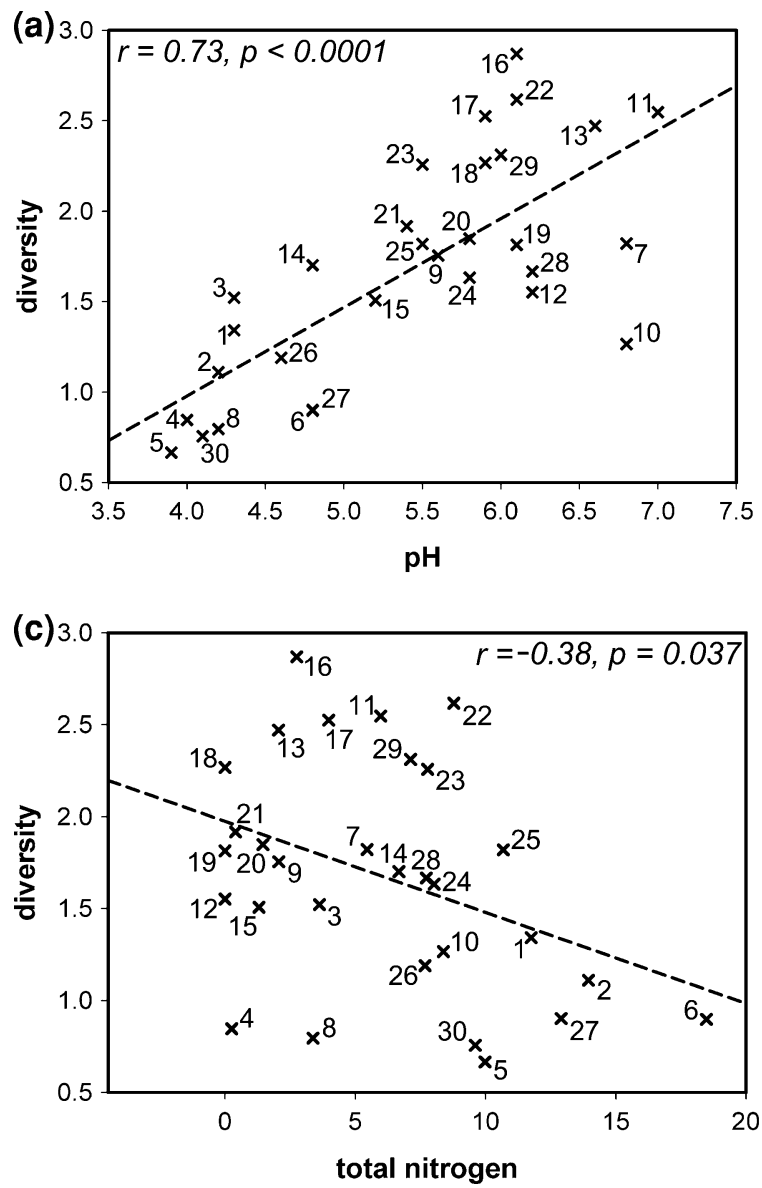

Fig. 4 The linear correlation analyses of the Shannon-Wiener index of species diversity with the $\mathrm{pH}$-value of the localities (a), the S-W index of species diversity with conductivity $\left(\mu \mathrm{Sm}^{-2}\right)(\mathbf{b})$, the $\mathrm{S}-\mathrm{W}$ index of species diversity with the

matrix were correlated with species diversity or richness. The normalized values of species diversity and partial morphological disparity (PD) of localities (based on the species counts) illustrated that locality no. 16 (a pool in Břehyně wetland, Czech Republic) had the highest diversity, and locality no. 26 (Črno jezero bog in Pohorje, Slovenia) had the highest contribution to the overall morphological disparity (Fig. 7). We observed that many minerotrophic localities with higher $\mathrm{pH}$ and relatively high diversity had comparatively lower disparity (e.g. localities no. $11,13-18,22-23$ ). On the other hand, most mountain peat bog localities had higher relative disparity in comparison to their species diversity (e.g. no. 4, 5, 8, 9, 26-29). The partial morphological disparity of the localities based on species counts was not correlated
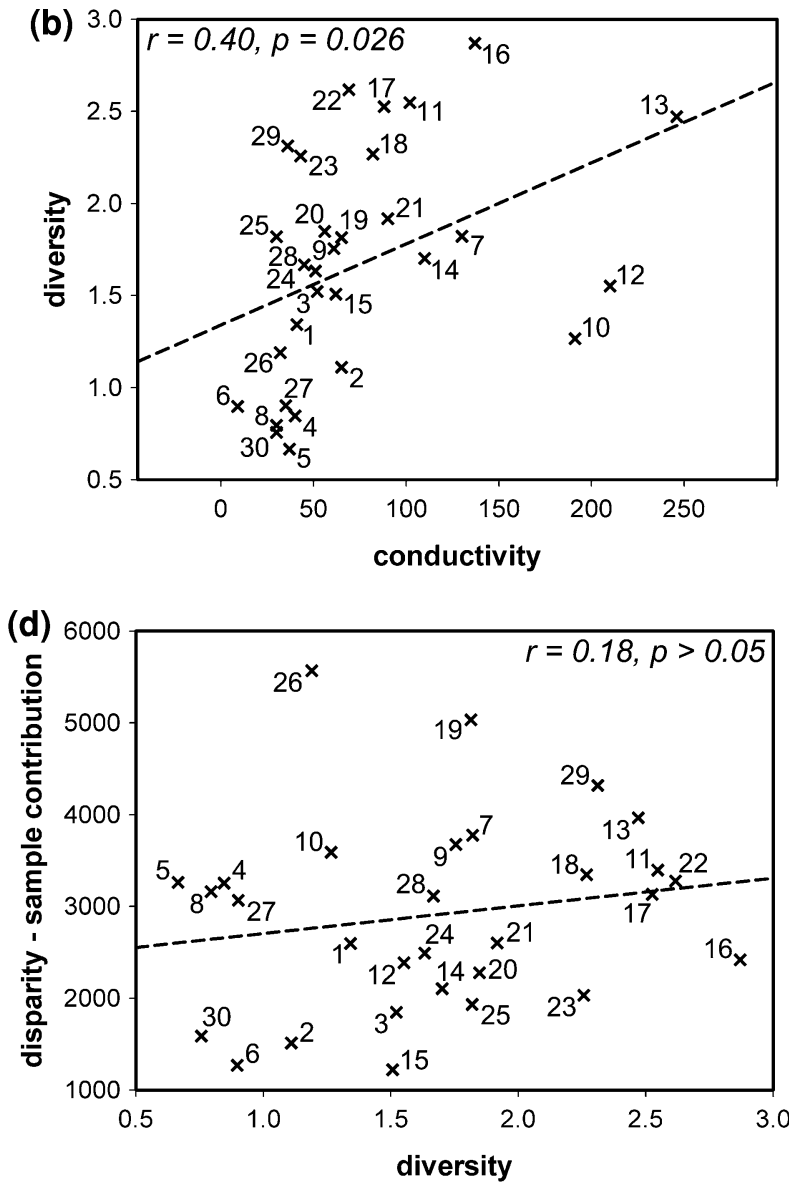

total nitrogen concentrations $\left(\mathrm{mg}^{-1}\right)$ (c) and the partial morphological disparity (based on the species counts) with the S-W index of species diversity (d)

with the measured abiotic factors. Conversely, the PD values based on the presence/absence of species matrix was weakly positively correlated with the $\mathrm{pH}$ of the localities $(r=0.41, P<0.027)$, and negatively correlated with the total nitrogen $(r=0.44$, $P<0.012$ ).

The inner morphological disparity (ID) of the localities measuring the morphological dissimilarity in members of a single sample (i.e. disparity of a sample) was highly correlated with species diversity ( $r=0.75, P<0.0001$ ) (Fig. 8a). The inner morphological disparity was also correlated with $\mathrm{pH}$ ( $r=0.60, P=0.0008$ ) (Fig. 8b), but it was not correlated with the other abiotic factors. The average cell complexity $(C)$ of the desmid assemblages in individual localities did not correlate with species 


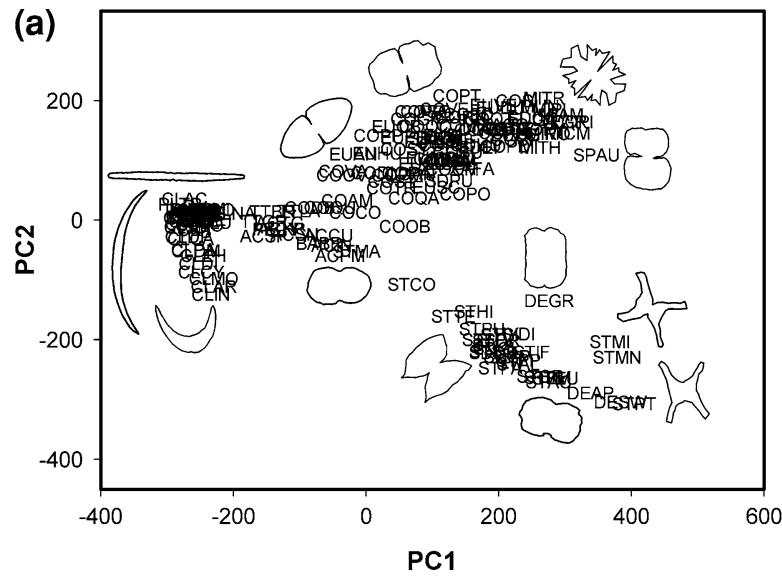

Fig. 5 The ordination plot of the first and second axes (a) and the third and fourth axes (b) of the PCA. The first axis (PC1) described $51.0 \%$, PC2 $17.8 \%$, PC $311.3 \%$ and PC4 $8.1 \%$ of the total variation in data. The species abbreviations correspond to

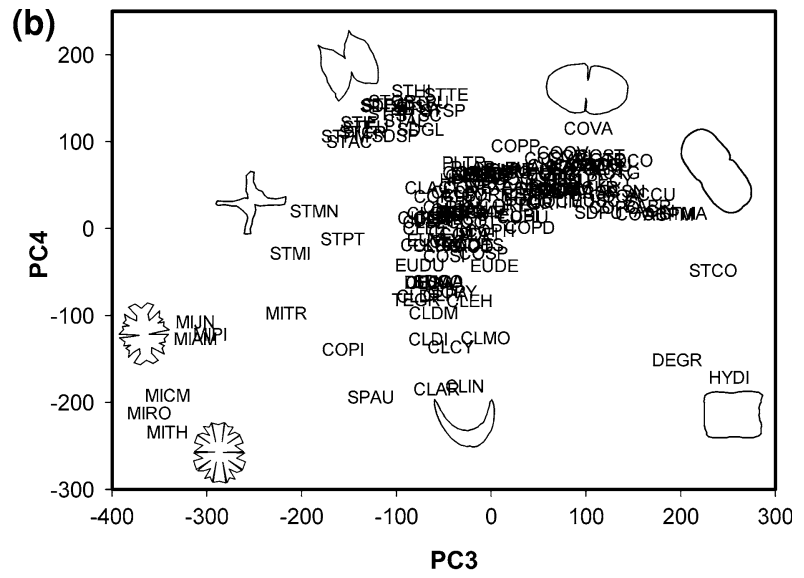

the Electronic supplementary material. The frontal outlines of selected cells with marginal positions on individual axes are illustrated
Fig. 6 The graphs of partial morphological disparity (a) measuring the contribution of individual species to the total variation within the morphospace and the complexity values (b) of individual species indicating the intricacy of their cells. The abbreviations of selected species are indicated and correspond to the Electronic supplementary material
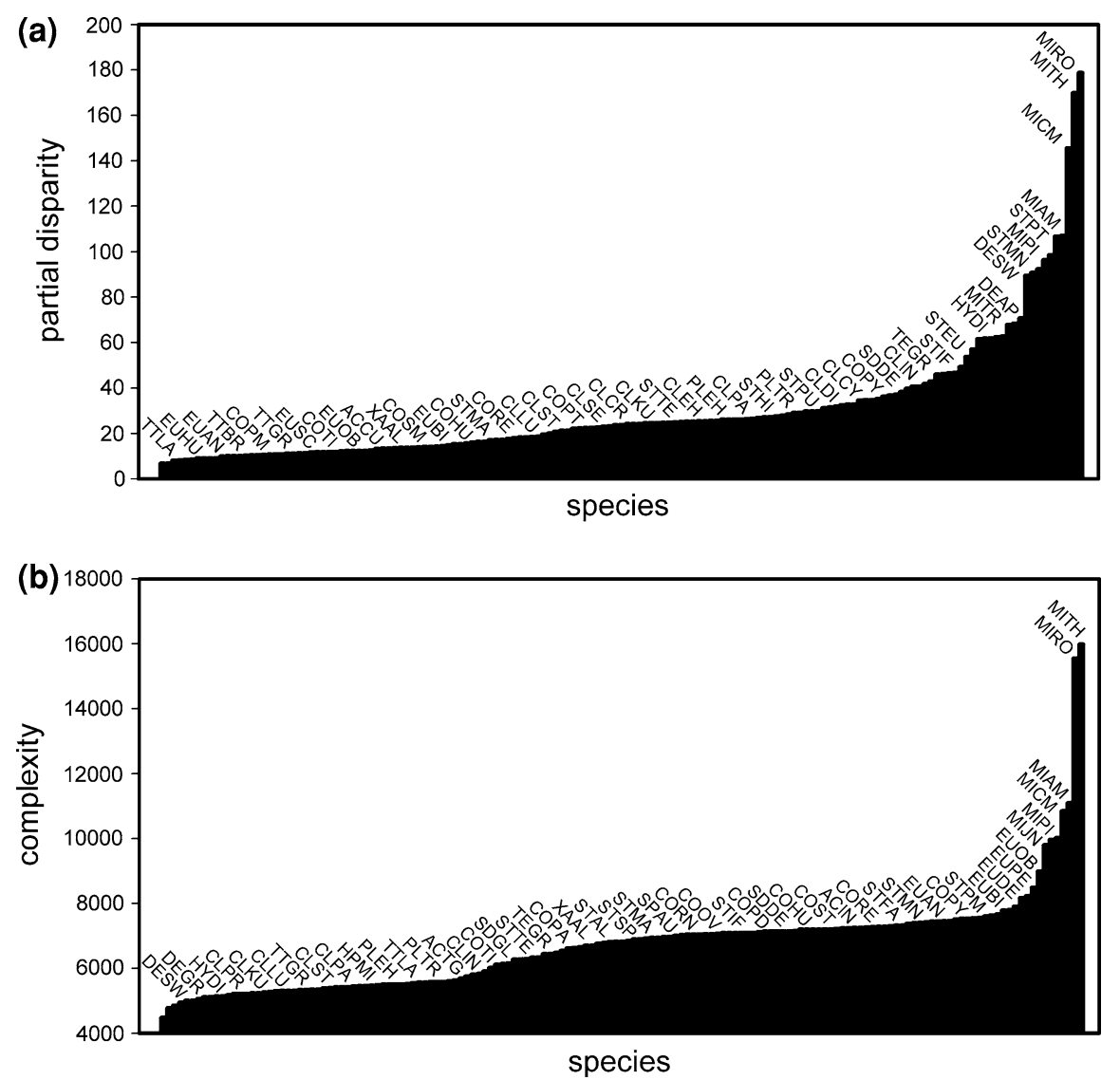

diversity or partial and inner morphological disparities. On the other hand, complexity positively correlated with the measures of total nutrient concentrations (total nitrogen: $r=0.47, P=0.0071$; total phosphorus: $r=0.40, P=0.0243$ ) (Fig. 8c, d). In general, the members of the genus Micrasterias had clearly the 


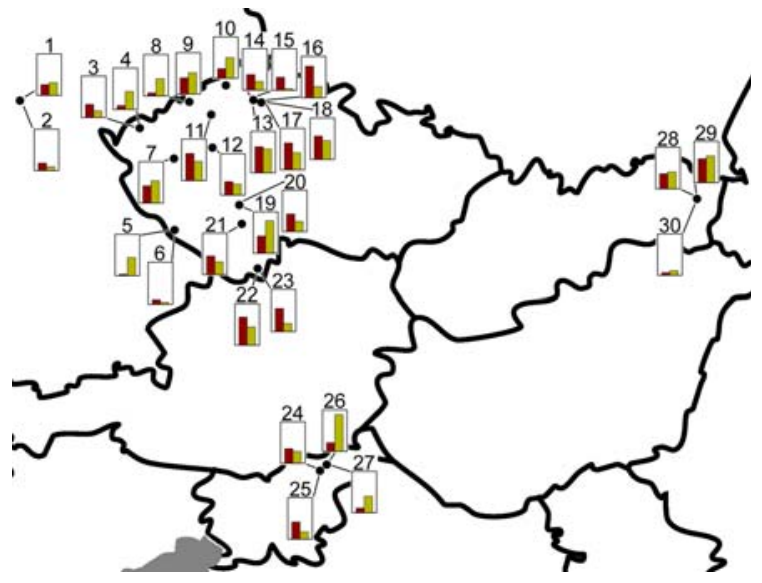

Fig. 7 The map of the investigated localities with their normalized Shannon-Wiener diversity indices in left columns, and the partial morphological disparity values (based on the quantitative species counts) in right columns

most complex cells (Fig. 6b). The Euastrum species, Staurastrum polymorphum and S. minimum, were the other species with relatively high cell complexity. Conversely, filamentous species, Desmidium swartzii, D. grevillei and Hyalotheca dissiliens, had the least complex cells. The cells of Closterium, Pleurotaenium and Haplotaenium species usually had low values for complexity, and most Cosmarium, Xanthidium, Actinotaenium and Staurastrum species had cells of average complexity.

\section{Discussion}

Species diversity of desmids in the investigated peatland benthic assemblages was positively correlated with $\mathrm{pH}$ of the localities. This phenomenon, also illustrated in other studies of benthic desmids (e.g. Coesel et al., 1978; Mataloni, 1999; Štěpánková et al., 2008), has usually been attributed to stress conditions of extremely low $\mathrm{pH}(<5.0)$ in many peat bog habitats that limits the occurrence of most species. In this study, the low $\mathrm{pH}$ localities typically had low richness with just a few species composing the actual assemblage. Certainly, by counting 100 cells, we did not record every desmid species occurring at a locality. This study was designed to evaluate the diversity versus disparity patterns based on the actual quantitative composition of assemblages, rather than to enumerate their total species richness, including very rare species. However, given the fact that our observed diversity patterns corresponded to previous published studies, we suppose that our data represented the overall differences in diversity of investigated localities. Coesel (2001) reported a unimodal response of species diversity of desmids to the $\mathrm{pH}$, with optima in slightly acidic to neutral conditions. As our study concentrated on peat bogs and fens, we did not sample more alkaline environments, and $\mathrm{pH}$ optima corresponded to the highest $\mathrm{pH}$-levels included within the investigated set. The species composition of low-pH localities showing low diversity values was more variable in comparison to higher-pH localities. The species-poor assemblages of acidic habitats differed considerably, and were much less predictable in their dominant desmid species. This phenomenon may be explained by the fluctuating and unstable environmental conditions of many acidified bog habitats (Turetsky \& St Louis, 2006), which led to the varying composition of their actual assemblages. Meanwhile, slightly acidic to neutral localities generally shared more species, and this was evident in the higher similarity of their species composition.

The $\mathrm{pH}$ and diversity gradients did not indicate the classic distinction between acidic ombrotrophic peat bogs and minerotrophic fens with higher $\mathrm{pH}$ values that was reported from boreal peatland ecosystems (Wheeler \& Proctor, 2000; Vitt, 2006). However, Hájek et al. (2006) illustrated different ecological dynamics of Central European mires that often reflected the nutrient status, rather than purely the $\mathrm{pH}$ gradient. In our study, several clearly minerotrophic localities had rather low $\mathrm{pH}$ (e.g. samples no. $14,15)$ and low amounts of available nutrients. However, the total nitrogen and, to a lesser extent, the total phosphorus concentrations significantly influenced the species composition, whereas the concentrations of soluble nutrient ions were not correlated with species data. This suggests the ability of many desmids to utilize the organic sources of nutrients in the generally oligotrophic conditions of peatlands (Spijkerman \& Coesel, 1998). Therefore, the total nitrogen and phosphorus concentrations may better correspond to actual species composition, than to the highly fluctuating and spatially variable concentrations of available ions (Walbridge \& Navaratnam, 2006). The total nitrogen concentrations better corresponded to both species composition and diversity. The weak, albeit still significant, negative correlation of total $\mathrm{N}$ 

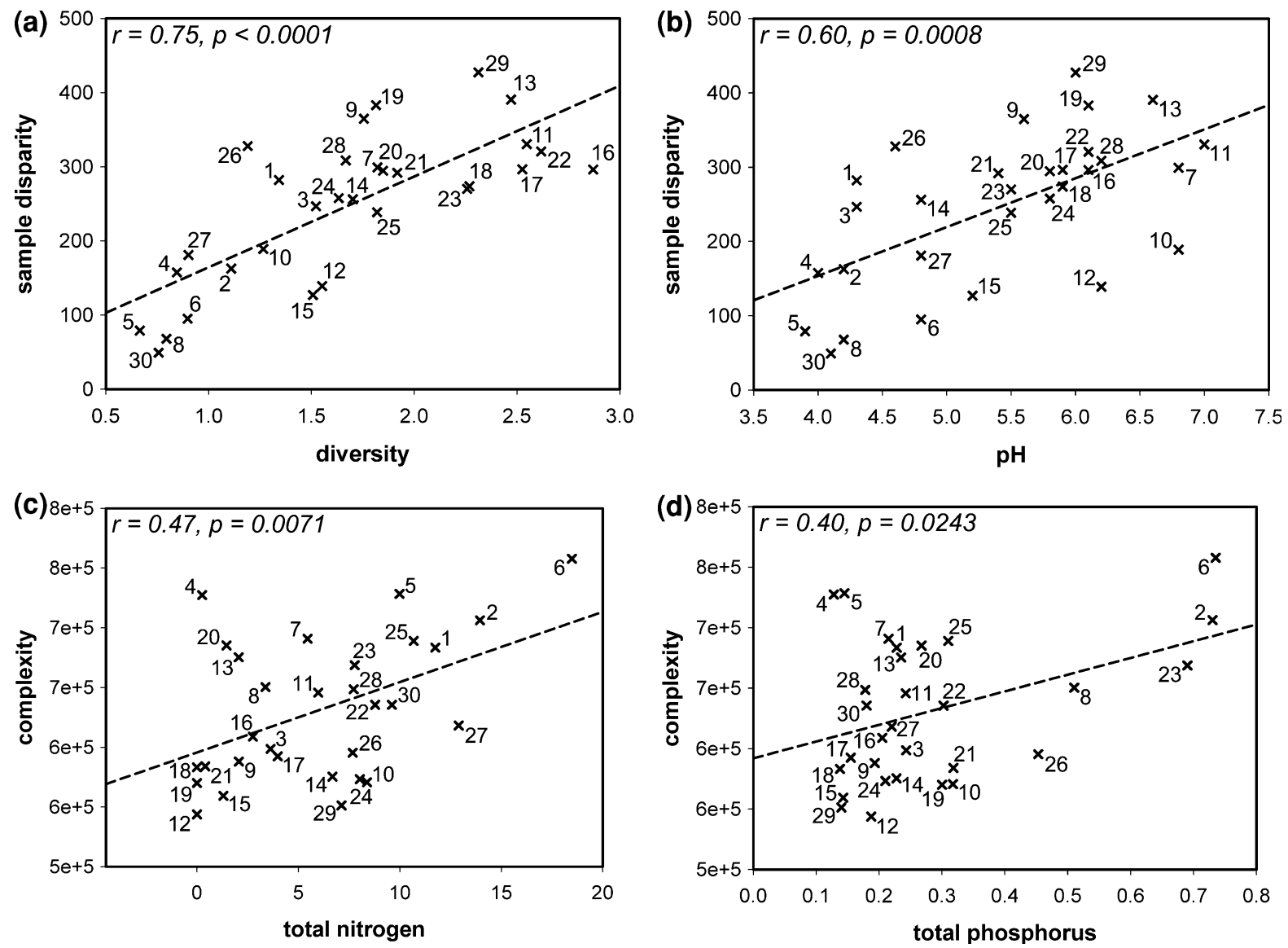

Fig. 8 The linear correlation analyses of the sample disparity levels with the Shannon-Wiener index of species diversity (a) the sample disparity with the $\mathrm{pH}$ values (b) the average cells complexity values of the localities with their total nitrogen

with species diversity are consistent with previous studies of Coesel et al. (1978) and Gilbert et al. (1998) that illustrated a general decrease of desmid diversity in relation to eutrophication of habitats.

The inner morphological disparity (i.e. disparity of a sample) of desmids from individual samples was correlated with their species diversity. This is predictable given the fact that most desmid taxa are defined by morphological characters. However, a much more intriguing result was the lack of any correlation between species diversity and partial morphological disparity of localities. The number of species in a given locality did not predict its disparity level. On the other hand, in some samples with low species diversity (presumably from mountain bogs), the disparity values were relatively high and, comparatively, localities with the highest diversity had average or lower disparity.

concentrations $\left(\mathrm{mg} \mathrm{l}^{-1}\right)(\mathbf{c})$ and the average cells complexity values of the localities with their total phosphorus concentrations $\left(\mathrm{mg} \mathrm{l}^{-1}\right)(\mathbf{d})$

Similar differences in disparity versus species diversity were previously demonstrated by several different groups (Roy et al., 2001; Neige, 2003a, 2006). Regions with high disparity values that often had relatively low species diversity are considered valuable from the conservational point of view as they harbor a significant portion of the group's morphospace. In this study, we observed high disparity in several mountain bog samples (e.g. the sample no. 26 from Črno Jezero peat bog in Pohorje Mts., or the sample no. 29 from Podstavka peat bog, Vihorlat Mts.). In addition, most mountain bog samples from the Sudeten mountains (e.g. the samples no. 4-5, 8-10) had comparatively high disparity in relation to their low species diversity. In these localities (mostly ombrotrophic mountain peat bogs), the desmid assemblages were relatively less diversified, but their disparity makes them important as 
they comprise a high proportion of the total morphospace of Desmidiales within the region. Obviously, in these low-diversity localities, this phenomenon was often caused by just a few or even a single dominant species with a high contribution to the total desmid disparity (e.g. Hyalotheca dissiliens). Thus, it is not unexpected that the partial morphological disparity values based on the presence/absence matrix (not taking into account the quantities of individual species) resulted rather in average PD values for these mountain peat bog localities (see Electronic supplementary material). However, together with their variability of species composition, the average or high contribution of the mountain bog localities to the overall morphological disparity of peatland Desmidiales demonstrates the importance of these habitats for Desmidiales in the region as a whole.

The presence/absence matrix-based measure of partial disparity also did not correlate with species richness data. The highest disparity based on presence/absence species data was found in minerotrophic localities no. 19 and 7. In both these cases, it coincided with the occurrence of Micrasterias species with high partial disparity values. There were some important differences in partial morphological disparity of individual species (measuring their eccentricity within the morphospace) and their cell complexity. While the species of Micrasterias had consistently the highest partial disparity, as well as cell complexity, most Euastrum species had low partial disparity (i.e. they were positioned close to the overall mean of the morphospace), but their cells had high complexity. Similarly, the cells of filamentous species, Hyalotheca dissiliens and Desmidium grevillei had high partial disparity, as they had quite eccentric cell shapes compared to other analyzed species, but their cell complexity was low. The lack of a correlation between average cell complexities of individual samples and their $\mathrm{pH}$ values did not correspond with the conclusions of Coesel (1982), who assumed higher incidence of more complex cell forms in localities with higher $\mathrm{pH}$. However, his study also incorporated the mesotaeniacean species that, as we now know from molecular data (e.g. Gontcharov, 2008), neither belong to, nor form a monophyletic group with, Desmidiales. While the 'flagship' species with the highest complexity values (as Micrasterias species), occurred typically in localities with average or higher $\mathrm{pH}$, some reasonably complex taxa (as e.g. Euastrum binale var. gutwinski and Cosmarium pygmaeum) were abundant in low $\mathrm{pH}$ localities. We should note that complexity of desmid cells is strictly a disparity measure, not an approximation of their surface-to-volume ratio ( $S / V$ ratio). Complexity is based on analysis of size-standardized shapes, whereas the $S / V$ ratios critically depend on size of the cells, in addition to their morphology. The evaluation of $S / V$ ratios for the complex cells of Desmidiales is extremely difficult, especially in taxa with the most complicated shapes, as e.g. Micrasterias, Euastrum and some Staurastrum species. In these taxa, application of classical geometric formulas approximating surfaces and volumes of cells as simple geometric objects (Hillebrand et al., 1999; Sun \& Liu, 2003) may not be appropriate. While the geometric formulas for calculation of $S / V$ ratios and biovolumes have often been successfully applied in phytoplankton studies (e.g. Salmaso \& Padisák, 2007; Crossetti \& Bicudo, 2008), the $S / V$ ratios of benthic desmids should probably be evaluated directly from the morphometric data. The original landmark configurations spanning outlines of cells may be used for approximation of their volumes and surfaces, possibly for all existing desmid shapes, but such procedures have yet to be developed. Clearly, the complexity measure used in this study may be related to the form resistance factor used for evaluation of sinking stress in phytoplankton (Padisák et al., 2003). Especially, in planktonic desmids may the changes in average cell complexity correlate with their ability to survive in the epilimnion of stratified water bodies. The morphometric evaluation of complexities in different planktonic natural assemblages could then be of much use for understanding the shape- and form-related life strategies of phytoplankton (NaselliFlores et al., 2007).

In this study, the average complexity of sample cells positively correlated with the nutrient concentration of their habitat. This pattern was rather surprising, as we know that increasing trophic status decreased diversity of assemblages (Coesel et al., 1978; Wayda, 2004, this study). This phenomenon certainly warrants further study. We propose an intriguing hypothesis that the complexity of cells, possibly reflecting complicatedness of their morphogenetic processes, increases in peatland environments with less nutrient-related stress. However, average complexity of assemblages certainly was also influenced by other critical factors, 
including ecological stability of individual localities. In this respect, the biomonitoring method of Coesel (2001, 2003), based on desmid species composition, which is related to ecological stability of habitats, could certainly be tested by quantitative disparity measures, such as the cell complexity value. Coesel (2001) included three separate series differing in their acidity, and each one constituted a gradient from a disturbed to stable habitat. The potential correlation of these series of Coesel's biomonitoring index with different disparity measures will be of interest in quantitative morphological studies to further elucidate the ecology of desmids. Clearly, definition of an overall 'desmid morphospace' containing all the species occurring within a particular region (e.g. temperate Central Europe) and/or habitat type would be of much interest for such studies. Comparison of such data based on an overall species list from a region (with known pH- or nutrients level affinity) with our data that were based on investigation of a limited number of localities may confirm, modify or disprove the conclusions of this study.

Acknowledgements This study was supported by the grant no. KJB601110921 of the Science Foundation of the Czech Academy of Sciences and by the research project of the Czech Ministry of Education no. 0021620828. The authors thank Dr. Marina Julian from JustMeEditing, Manuscript Editor for the Biological Sciences for the language and style corrections. The authors thank the reviewers for their suggestions that led to some useful additions to the manuscript.

\section{References}

Beszteri, B., E. Ács \& L. Medlin, 2005. Conventional and geometric morphometric studies of valve ultrastructural variation in two closely related Cyclotella species (Bacillariophyta). European Journal of Phycology 40: 89103.

Bicudo, C. E. M. \& F. Gil-Gil, 2003. Different morphological expressions or taxonomical entities of Micrasterias arcuata (Desmidiales, Zygnemaphyceae)? Biologia 58: 645-655.

Borics, G., B. Tóthmérész, I. Grigorszky, J. Padisák, G. Várbíró \& S. Szabó, 2003. Algal assemblage types of boglakes in Hungary and their relation to water chemistry, hydrological conditions and habitat diversity. Hydrobiologia 502: 145-155.

Clabaut, C., P. M. E. Bunje, W. Salzburger \& A. Meyer, 2007. Geometric morphometric analyses provide evidence for the adaptive character of the Tanganyikan cichlid fish radiations. Evolution 61: 560-578.
Coesel, P. F. M., 1982. Structural characteristics and adaptations of desmid communities. Journal of Ecology 70: 163-177.

Coesel, P. F. M., 2001. A method for quantifying conservation value in lentic freshwater habitats using desmids as indicator organisms. Biodiversity and Conservation 10: 177187.

Coesel, P. F. M., 2003. Desmid flora data as a tool in conservation management of Dutch freshwater wetlands. Biologia 58: 717-722.

Coesel, P. F. M. \& J. Meesters, 2007. Desmids of the lowlands. KNNV Publishing, Zeist.

Coesel, P. F. M., R. Kwakkestein \& A. Verschoor, 1978. Oligotrophication and eutrophication tendencies in some Dutch moorland pools, as reflected in their desmid flora. Hydrobiologia 61: 21-31.

Crossetti, L. O. \& C. E. M. Bicudo, 2008. Adaptations in phytoplankton life strategies to imposed change in a shallow urban tropical eutrophic reservoir, Garcas Reservoir, over 8 years. Hydrobiologia 614: 91-105.

Dryden, I. L. \& K. V. Mardia, 1998. Statistical shape analysis. John Wiley \& Sons, New York.

Foote, M., 1993. Contributions of individual taxa to overall morphological disparity. Paleobiology 19: 403-419.

Fortin, M. J. \& J. Gurevitch, 1993. Mantel tests: spatial structure in field experiments. In Scheiner, S. M. \& J. Gurevitch (eds), Design and Analysis of Ecological Experiments. Chapman \& Hall, New York: 342-359.

Gilbert, D., C. Amblard, G. Bouldier \& A.-J. Francez, 1998. Short-term effect of nitrogen enrichment on the microbial communities of a peatland. Hydrobiologia 373(374): 111119.

Gontcharov, A. A., 2008. Phylogeny and classification of Zygnematophyceae (Straptophyta): current state of affairs. Fottea 8: 87-104.

Hájek, M., M. Horsák, P. Hájková \& D. Dítě, 2006. Habitat diversity of central European fens in relation to environmental gradients and an effort to standardise fen terminology in ecological studies. Perspectives in Plant Ecology, Evolution and Systematics 8: 97-114.

Hall, J. D., K. G. Karol, R. M. McCourt \& C. F. Delwiche, 2008. Phylogeny of the conjugating green algae based on chloroplast and mitochondrial nucleotide sequence data. Journal of Phycology 44: 467-477.

Hammer, Ø., D. A. T. Harper \& P. D. Ryan, 2001. PAST: paleontological Statistics Software package for education and data analysis. Palaeontlogia Electronica 4: 1-9.

Hillebrand, H., C. D. Dürselen, D. Kirschtel, U. Pollingher \& T. Zohary, 1999. Biovolume calculation for pelagic and benthic microalgae. Journal of Phycology 35: 403-424.

Hoagstrom, C. W. \& C. R. Berry, 2008. Morphological diversity among fishes in a Great Plains river drainage. Hydrobiologia 596: 367-386.

Jolliffe, I. T., 1986. Principal Component Analysis. Springer, New York.

Kruskal, J. B., 1964. Nonmetric multidimensional scaling: a numerical method. Psychometrika 29: 115-129.

Lenzenweger, R., 2003. On the geographically isolated occurrence of some rare Austrian desmid species. Biologia 58: 657-660.

Lestrel, P. E., 1997. Fourier Descriptors and their Applications in Biology. Cambridge University Press, Cambridge. 
Lestrel, P. E., 2000. Morphometric for the Life Sciences. World Scientific Publishing Company, Singapore.

Magurran, A. E., 2004. Measuring Biological Diversity. Blackwell Publishing, Oxford.

Mantel, N., 1967. The detection of disease clustering and a generalized regression approach. Cancer Research 27: 209-220.

Mataloni, G., 1999. Ecological studies on algal communities from Tierra del Fuego peat bogs. Hydrobiologia 391: 157-171.

McClain, C. R., N. A. Johnson \& M. A. Rex, 2004. Morphological disparity as a biodiversity metric in lower bathyal and abyssal gastropod assemblages. Evolution 58: 338348.

Naselli-Flores, L., J. Padisák \& M. Albay, 2007. Shape and size in phytoplankton ecology: do they matter? Hydrobiologia 578: 157-161.

Neige, P., 2003a. Spatial patterns of disparity and diversity of the recent cuttlefishes (Cephalopoda) across the Old World. Journal of Biogeography 30: 1125-1137.

Neige, P., 2003b. Combining disparity with diversity to study the biogeographic pattern of Sepiidae. Berliner Paläobiologischer Abhandlungen 3: 189-197.

Neige, P., 2006. Morphometrics of hard structures in cuttlefish. Vie et Milieu - Life \& Environment 56: 121-127.

Neustupa, J. \& J. Št'astný, 2006. The geometric morphometric study of Central European species of the genus Micrasterias (Zygnematophyceae, Viridiplantae). Preslia 78: 253-263.

Neustupa, J. \& P. Škaloud, 2007. Geometric morphometrics and qualitative patterns in the morphological variation of five species of Micrasterias (Zygnemophyceae, Viridiplantae). Preslia 79: 401-417.

Neustupa, J., J. Št'astný \& L. Hodač, 2008. Temperaturerelated phenotypic plasticity in the green microalga $\mathrm{Mi}$ crasterias rotata. Aquatic Microbial Ecology 51: 77-86.

Nováková, S., 2002. Algal flora of subalpine peat bog pools in the Krkonoše Mts. Preslia 74: 45-56.

Padisák, J., E. Soróczki-Pintér \& Z. Rezner, 2003. Sinking properties of some phytoplankton shapes and the relation of form resistance to morphological diversity of plankton-an experimental study. Hydrobiologia 500: 243257.

Pappas, J. L., G. W. Fowler \& E. F. Stoermer, 2001. Calculating shape descriptors from Fourier analysis: shape analysis of Asterionella (Heterokontophyta, Bacillariophyceae). Phycologia 40: 440-456.

Potapova, M. \& P. B. Hamilton, 2007. Morphological and ecological variation within the Achnanthidium minutissimum (Bacillariophyceae) species complex. Journal of Phycology 43: 561-575.

Prescott, G. W., H. T. Croasdale \& W. C. Vinyard, 1977. A Synopsis of North American Desmids, Part II. Desmidiaceae: Placodermae, Sect. 2. University of Nebraska Press, Lincoln.

Purvis, A. \& A. Hector, 2000. Getting the measure of biodiversity. Nature 405: 212-219.

R Development Core Team, 2006. R: A Language and Environment for Statistical Computing. R Foundation for Statistical Computing, Vienna.
Ralfs, J., 1848. The British Desmidieae. Reeve, Benham and Reeve, London.

Rohlf, F. J., 2003. EFA3D, ver 1.0. Department of Ecology and Evolution, State University of NewYork at Stony Brook, New York.

Rohlf, F. J., 2008. TpsDig, ver 2.12. Department of Ecology and Evolution, State University of NewYork at Stony Brook, New York.

Roy, K. \& M. Foote, 1997. Morphological approaches to measuring biodiversity. Trends in Ecology and Evolution 12: 277-281.

Roy, K., D. P. Balch \& M. E. Hellberg, 2001. Spatial patterns of morphological diversity across the Indo-Pacific: analyses using strombid gastropodes. Proceedings of the Royal Society London B 268: 2503-2508.

Růžička, J., 1977. Die Desmidiaceen Mitteleuropas, Band 1, 1. Lieferung. E. Schweizerbart'sche Verlagsbuchhandlung, Stuttgart.

Růžička, J., 1981. Die Desmidiaceen Mitteleuropas, Band 1, 2. Lieferung. E. Schweizerbart'sche Verlagsbuchhandlung, Stuttgart.

Salmaso, N. \& J. Padisák, 2007. Morpho-functional groups and phytoplankton development in two deep lakes (Lake Garda, Italy and Lake Stechlin, Germany). Hydrobiologia 578: 97-112.

Spijkerman, E. \& P. F. M. Coesel, 1998. Alkaline phosphatase activity in two planktonic desmid species and the possible role of an extracellular envelope. Freshwater Biology 39: 503-513.

Štěpánková, J., J. Vavrušková, P. Hašler, P. Mazalová \& A. Poulíčková, 2008. Diversity and ecology of desmids of peat bogs in the Jizerské hory Mts. Biologia 63: 895-900.

Sun, J. \& D. Y. Liu, 2003. Geometric models for calculating cell biovolume and surface area for phytoplankton. Journal of Plankton Research 25: 1331-1346.

Tomaszewicz, G. H., 1994. Abundance and composition of the desmid flora in a series of peat pits, in relation to $\mathrm{pH}$ and some other habitat parameters. Biologia 49: 519-524.

Turetsky, M. R. \& V. L. St Louis, 2006. Disturbance in boreal peatlands. In Wieder, R. K. \& D. H. Vitt (eds), Boreal Peatland Ecosystems. Springer Verlag, Berlin: 359-379.

Vitt, D. H., 2006. Functional characteristics and indicators of boreal peatlands. In Wieder, R. K. \& D. H. Vitt (eds), Boreal Peatland Ecosystems. Springer Verlag, Berlin: 924.

Walbridge, M. R. \& J. A. Navaratnam, 2006. Phosphorous in boreal peatlands. In Wieder, R. K. \& D. H. Vitt (eds), Boreal Peatland Ecosystems. Springer Verlag, Berlin: 231-258.

Wayda, M., 2004. Changes in species composition of desmids in the "Bloto" peat bog (the Niepolomice Forest) from 1954 to 2001. Acta Societatis Botanicorum Poloniae 73: 239-246.

Wheeler, B. D. \& M. C. F. Proctor, 2000. Ecological gradients, subdivisions and terminology of north-west European mires. Journal of Ecology 88: 187-203.

Zelditch, M. L., D. L. Swiderski, D. H. Sheets \& W. L. Fink, 2004. Geometric Morphometrics for Biologists: A Primer. Elsevier Academic Press, London. 